Sains Malaysiana 49(2)(2020): 405-410

http://dx.doi.org/10.17576/jsm-2020-4902-19

\title{
Xanthine Oxidase Inhibitory Activity of Methanolic Extract of Alternanthera sessilis
}

(Aktiviti Rencatan Xantina Oksidase Ekstrak Metanol Alternanthera sessilis)

\author{
ChOng Sharmaine \& LOH KHYE ER*
}

\begin{abstract}
Gout is caused by abnormal high level of uric acid in the body resulting from the deposition of urate crystals. Uric acid is the end product of purine metabolism in which xanthine oxidase (XO) catalyzes the oxidation of hypoxanthine and xanthine to uric acid. Allopurinol, an effective anti-hyperuricemic agent has limited clinical usage due to its adverse reactions. Therefore, it is very urgent to search for better phytochemicals, which possess ability as xanthine oxidase inhibitor. In the present study, hydromethanolic extract of red and green sessile joyweed, Alternanthera sessilis was evaluated for its in vitro XO inhibitory potential. Enzyme kinetic was determined using Lineweaver-Burk plot. Methanolic extract of green sessile joyweed showed higher XO inhibition compared to red sessile joyweed. The IC $C_{50}$ of XO inhibitory activity for green sessile joyweed was $557.77 \pm 56.47 \mu \mathrm{g} / \mathrm{mL}$. The mode of inhibition for red and green sessile joyweed was uncompetitive and non-competitive, respectively. The potential of green sessile joyweed as a source of natural XO inhibitor in the treatment of hyperuricemia or gout has been reported for the first time.
\end{abstract}

Keywords: Green sessile joyweed; mode of inhibition; red sessile joyweed; xanthine oxidase inhibitor

ABSTRAK

Gout adalah disebabkan oleh asid urik yang berlebihan di dalam badan yang mengakibatkan pemendapan kristal gram urik. Asid urik adalah produk akhir metabolisma purin dengan xantina oksidase memangkinkan oksidasi hipoxantina dan xantina kepada asid urik. Penggunaan klinikal alopurinol, sejenis ejen anti-hiperurisemik yang efektif, menjadi terhad disebabkan oleh kesannya yang buruk. Maka, pencarian bahan kimia tumbuhan yang lebih baik dan mempunyai keupayaan sebagai perencat xantina oksidase perlu dipercepatkan. Dalam kajian ini, potensi perencatan xantina oksidase secara in vitro bagi ekstrak hidro-metanol keremak merah dan hijau (Alternanthera sessilis) telah dikaji. Kinetik enzim juga telah dijalankan dengan menggunakan plot Lineweaver-Burk. Keremak hijau didapati mempunyai kuasa perencatan xantina oksidase yang lebih tinggi berbanding dengan keremak merah. $I_{50}$ bagi aktiviti perencatan xantina oksidase keramak hijau adalah $557.77 \pm 56.47 \mu \mathrm{g} / \mathrm{mL}$. Mod perencatan bagi keremak merah dan hijau adalah masing-masing tak berpersaingan dan tidak- berpersaingan. Potensi keremak hijau sebagai sumber perencatan xantina oksidase semula jadi dalam rawatan hiperurisemia dan gout telah dilaporkan buat kali pertama.

Kata kunci: Keremak hijau; keremak merah; mod perencatan; perencat xantina oksidase

\section{INTRODUCTION}

Gout is a painful inflammatory arthritis due to the deposition of monosodium urate crystal in the joints or tissues (Chen et al. 2011). A sudden attack of gout causes severe pain and swell in the joints such as foot, ankle or knees. Although there is no published statistics on the prevalence of gout in Malaysia, it is one of the most commonly seen arthritis (Khuan et al. 2008). The factors of gout risk include genetics, age, gender and lifestyle (Corp \& Pendry 2013). Gout is associated with hyperuricemia and may develop as a result of uric acid under excretion or urate overproduction. Xanthine oxidase (XO) is a versatile enzyme present in liver and intestinal mucosa that catalyzes the formation of uric acid from purine in the body (Sweeney et al. 2001). Uric acid is formed mainly from the liver and excreted in the urine (Chaudhary et al. 2013). Excessive uric acid in blood will lead to urate formation, resulting in painful and swollen joint. It can also cause kidney stone when the crystal is deposited in the kidney and some patients may eventually go on to develop kidney failure (Khuan et al. 2008). Gout is linked to other diseases when it comes to a critical stage such as high blood pressure, obesity and diabetes (Umamaheswari et al. 2008).

Nonsteroidal Anti-inflammatory Drugs (NSAIDs) and colchicine are commonly used in relieving pain and reducing inflammation in patients with acute gout. The treatments are associated with side effects that limit the usefulness, such as nausea, vomiting and diarrhea. Allopurinol, a XO inhibitor, is one of the most available hypouricemic drug in Malaysia. It can be used to block the catalysis of xanthine to uric acid effectively by serving as a competitive inhibitor of the XO enzyme. However, the adverse effects of allopurinol such as allergic response, 
bone marrow suppression, hepatitis, jaundice and progressive renal failure has limited its clinical usage (Khuan et al. 2008). Therefore, it is urgent to search for a more effective anti-hyperuricemic or anti-gout agent from the natural resources with lesser side effects.

Alternanthera sessilis is widely used in medicine and served as food. The shoots and leaves are consumed for its high nutrient content including iron, vitamin A and dietary fibers. It is used by the folk medicine practitioners to cure asthma, fever, skin disease, diarrhea and hemorrhoids (Hossain et al. 2014). Besides, A. sessilis has also been shown to possess anti-inflammatory, antioxidant and anti-bacterial activity by some researchers (Kota et al. 2017; Othman et al. 2016; Sahithi et al. 2011). To the best of our knowledge, there is no reported research on the XO inhibition of $A$. sessilis extract. In the present study, the XO inhibitory activity of two types of $A$. sessilis, red and green joyweed, was compared. The potential of $A$. sessilis as a source of natural XO inhibitor in the treatment of hyperuricemia or gout and its mode of inhibition was reported for the first time.

\section{MATERIALS AND METHODS}

\section{PLANT MATERIALS}

Approximately $1.4 \mathrm{~kg}$ of fresh red A. sessilis (ASR) was collected from wet market in Gombak, Kuala Lumpur and about one $\mathrm{kg}$ of fresh green $A$. sessilis (ASG) was collected from wet market in Klang, Selangor. Both plants are originated from Selangor, Malaysia. Authentication of the plant sample was carried out at Herbarium UKMB, Faculty of Science and Technology, Universiti Kebangsaan Malaysia and the specimen voucher for red (UKMB40449) and green (UKMB40450) sessile joyweeds was deposited. The plants were washed with distilled water and padded dry. The stem and leaves were cut into small pieces and shade dried for 7 days at room temperature. The air dried samples were first ground in a blender and sieved through a stainless steel mesh. Both samples were kept separately in small plastic bag and stored at $-20^{\circ} \mathrm{C}$.

\section{PLANT EXTRACTION}

The powdered samples were soaked in $80 \%$ methanol in the ratio of 1:6 (w/v) and agitated on an orbital shaker at $140 \mathrm{rpm}$ for $24 \mathrm{~h}$. The extracts were filtered through Whatman number 1 filter paper after $24 \mathrm{~h}$ and the extraction was repeated twice on the plant residues. The extracts were pooled and evaporated using rotary evaporator (Buchi $\mathrm{R}-100$ system) and kept at $-80^{\circ} \mathrm{C}$ until analysis.

\section{XANTHINE OXIDASE INHIBITORY ASSAY}

XO inhibitory assay was modified from Sweeney et al. (2001) method. The XO enzyme was purchased from Roche Diagnostics, Germany and xanthine substrate was purchased from Sigma-Aldrich, United States. All other chemicals were of analytical grade. The substrate and the enzyme solutions were prepared immediately before use. The test samples were dissolved in dimethyl sulfoxide and diluted to various concentrations $(12.5-400 \mu \mathrm{g} / \mathrm{mL})$. The assay mixture consisted of $130 \mu \mathrm{L}$ of $0.05 \mathrm{M}$ potassium phosphate buffer (pH7.5), $10 \mu \mathrm{L}$ of sample, $10 \mu \mathrm{L}$ of 0.1 unit/mL XO enzyme solution. After pre-incubation for 10 min at $25^{\circ} \mathrm{C}$, the reaction was then initiated by the addition of $100 \mu \mathrm{L}$ xanthine $(0.15 \mathrm{mM})$ solution and incubated for $10 \mathrm{~min}$ at $30^{\circ} \mathrm{C}$. The enzymatic conversion of xanthine to form uric acid and hydrogen peroxides measured at absorbance of $295 \mathrm{~nm}$. All reactions were performed in triplicates in a 96-well UV microplate. A negative control was prepared containing the assay mixture without the extract. Allopurinol was used as a positive control in the assay mixture. The XO inhibitory activity was calculated as:

XO Inhibition $(\%)=($ Control absorbance - Sample absorbance $)$ / Control absorbance $\times 100 \%$

The $\mathrm{IC}_{50}$ values of the test samples were determined from regression lines of a plot of the percentage of inhibition on $\mathrm{XO}$ activity versus the concentrations of the samples. The $\mathrm{IC}_{50}$ for allopurinol was also determined.

\section{MODE OF XANTHINE OXIDASE INHIBITION}

Enzyme kinetic was determined in the absence and presence of test samples with varying concentrations of xanthine substrate $(30,75,150,225$ and $300 \mu \mathrm{M})$ using the XO inhibitory assay (Lin et al. 2015). Allopurinol was used as the positive control. Lineweaver-Burk plots were plotted by the reciprocal velocity $(1 / \mathrm{v})$ versus the concentration of the substrate $(1 /$ [xanthine $])$.

\section{STATISTICAL ANALYSIS}

The data obtained from the present study was analysed using SPSS (Statistical Package for Social Sciences) version 21 . The data was subjected to normality test and tested for homogeneity of variance using Levene's test. One-way Analysis of Variance (ANOVA) with post-hoc Duncan test was used to analyse the differences between treatments. A significant level of $\mathrm{p}<0.05$ was considered throughout the analysis.

\section{RESULTS AND DISCUSSION}

The yield of the crude hydromethanolic extract for the ASR and ASG was $6.67 \mathrm{~g}$ and $12.85 \mathrm{~g}$, respectively. In the present study, XO inhibitory activity of the ASR and ASG extracts were investigated, with allopurinol as positive control. One-way ANOVA analysis showed that both ASR and ASG hydromethanolic extracts have XO inhibitory activity ranging from $10-85 \%$ at different concentration (Figure 1). It might be contributed by the bioactive compounds present in the ASR and ASG extracts. A. sessilis 
has been shown to contain total flavonoids and crude phenolics of $0.370 \mathrm{mg} / \mathrm{gm}$ dry weight and $1.529 \mathrm{mg} / \mathrm{gm}$ dry weight, respectively (Borah et al. 2011). According to Othman et al. (2016), both plants possessed almost the same phenolic compounds with slight differences due to variation between species. Many studies have reported the XO inhibitory activity of phenolic constituents like chlorogenic acid and ferulic acid (Gawlik-Dziki et al. 2017; Qu et al. 2017).

Based on the results, the ASG extract was significantly more effective $(p<0.05)$ than the ASR in XO inhibition at $750-1000 \mu \mathrm{g} / \mathrm{mL}$. The high inhibition of more than $75 \%$ at these concentrations was not significantly different from that of the positive control, allopurinol. The ASR was more effective than ASG in XO inhibition at lower concentration of $125 \mu \mathrm{g} / \mathrm{mL}$ and $250 \mu \mathrm{g} / \mathrm{mL}$. This might be due to the greater amount of bioactive compounds present in the ASR extract confer to its higher bioactivity at lower concentration. The results are in accordance to the findings reported by Othman et al. (2016) that the ASR contained significantly higher total phenolic content than the ASG.

Although ineffective at lower concentration, the XO inhibition of ASG increased in a dose-dependent manner while insignificant change was observed in ASR when the concentration of test sample increased from $100-1000$ $\mu \mathrm{g} / \mathrm{mL}$. This might be due to a more potential XO inhibitor is possibly present in the ASG although its total phenolic content was in general lower than that of the ASR. Catechin, a phenolic compound that is more abundant in the ASG extract (Othman et al. 2016) was suggested to be one of the potential XO inhibitor in this study. Catechin from green tea extracts has been shown to significantly reduced XO activity in a study by Rashidinejad et al. (2016). Other than that, the different mode of inhibition exhibited by different bioactive compounds present in ASR and ASG might also contributed to the differences in the inhibitory pattern.

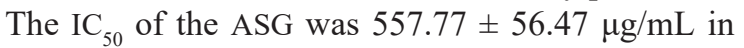
comparison to that of the allopurinol of $6.1 \mu \mathrm{g} / \mathrm{mL}$. The high $\mathrm{IC}_{50}$ of the hydromethanolic extracts of ASG relative to the allopurinol drug is due to the lower purity of the crude extract since fractionation and purification is yet to be carried out. The allopurinol drug with purity of more than $99 \%$ was expected to possess low $\mathrm{IC}_{50}$ value as compared to plant crude extract. The results suggested that the ASG extract can be further fractionated to increase the purity of the extract and thus, the inhibitory potential of the fraction at lower effective concentration. Allopurinol was used in this study since there is no comparative plant extract to be used as positive control. Although the XO inhibitory effect of a complex mixture of crude extract could not be directly compared to a pure compound, the results showed that both the ASG and ASR extract might be a potential source of XO inhibitor, in which the extracts might exhibit higher $\mathrm{XO}$ inhibition at higher concentration or purity.

For the enzyme kinetic assay, the mode of XO inhibition was uncompetitive inhibition for ASR (Figure $2)$. This indicated that the inhibitor from the ASR extract

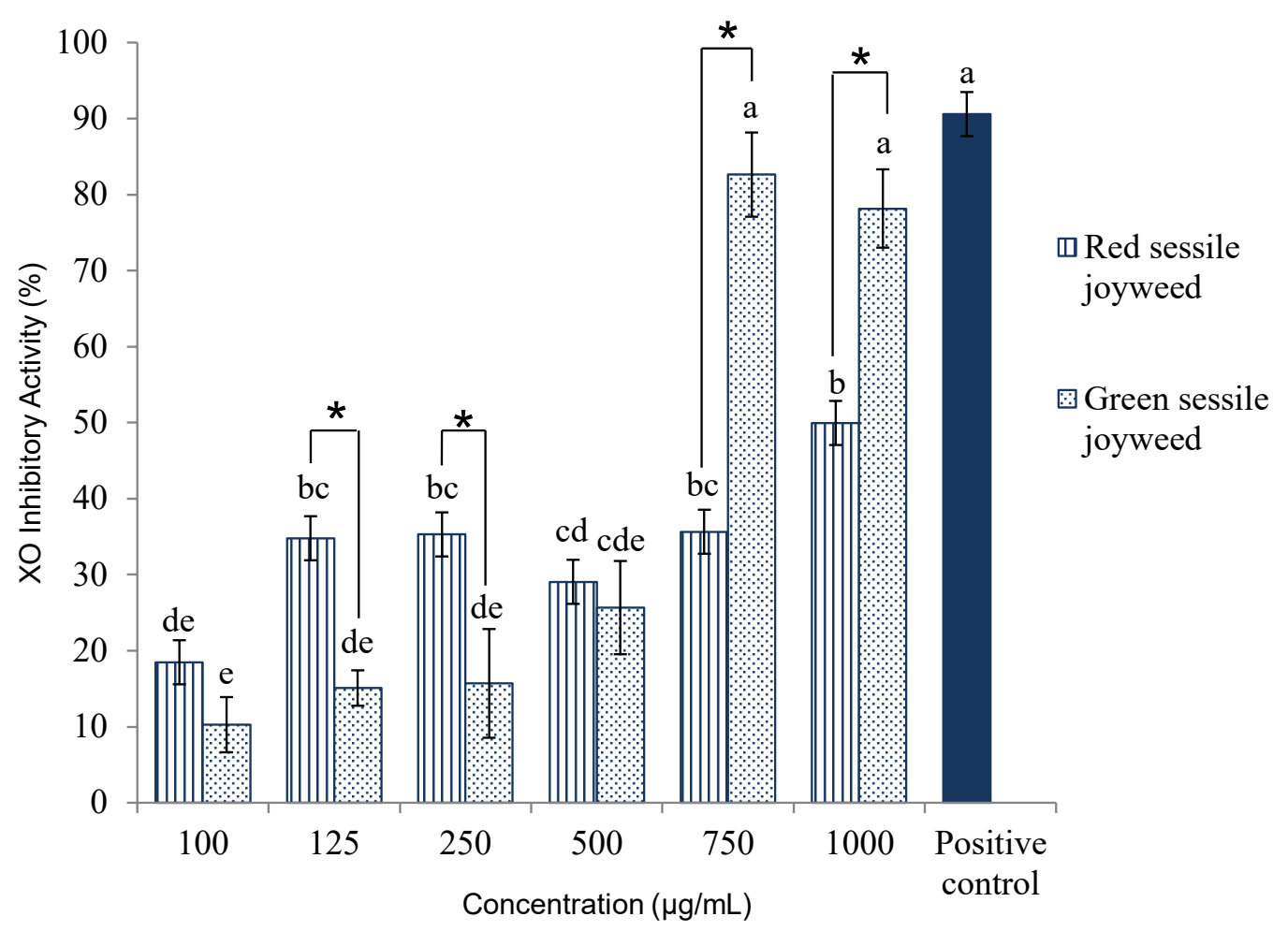

FIGURE 1. Xanthine oxidase inhibitory activity for red sessile joyweed and green sessile joyweed at various concentrations. Values are mean \pm SEM $(n=3)$. Significant differences were compared between different concentrations and positive control. Similar letter showed no significant difference and asterisk indicate significant difference at $\mathrm{p}<0.05$ between red and green sessile joyweed 
might be bound to the enzyme-substrate complex and inhibited the uric acid production. Whereas the mode of XO inhibitory activity for ASG was non-competitive inhibition (Figure 3), which might reduce the activity of the enzyme by binding to its allosteric site. As the inhibitor binds to the enzyme and the enzyme-substrate complex, it reduces the concentration of enzyme available for proper catalysis (Berg et al. 2007), thereby lowering the uric acid production. This demonstrated that the bioactive compound contributed to the XO inhibition in ASR and ASG in the present study might be different. Furthermore, the noncompetitive inhibition demonstrated by the ASG extract is a more commonly reported mode in previous XO inhibitory studies, in which phenolic compound is commonly deciphered as the inhibitor. In other words, both varieties of $A$. sessilis might possessed XO inhibitory activity via different mechanisms.

A. sessilis has been shown to possess anti-inflammatory activity, which might be related to the XO inhibitory activity. Phytochemical constituents present in $A$. sessilis include alkaloids, terpenoids, flavonoids, tannins, saponins, polyphenols, cardiac glycosides and quinones (Kanagarasu et al. 2017). Flavonoid has been reported to possess a high potential for inhibition of XO due to its structure (Lin et al. 2015). Quercetin has been isolated from A. sessilis (Vani et al. 2018) and shown to be a fully reversible and noncompetitive XO inhibitor (Zhang et al. 2018). Other polyphenolic compounds, namely ferulic acid, rutin and

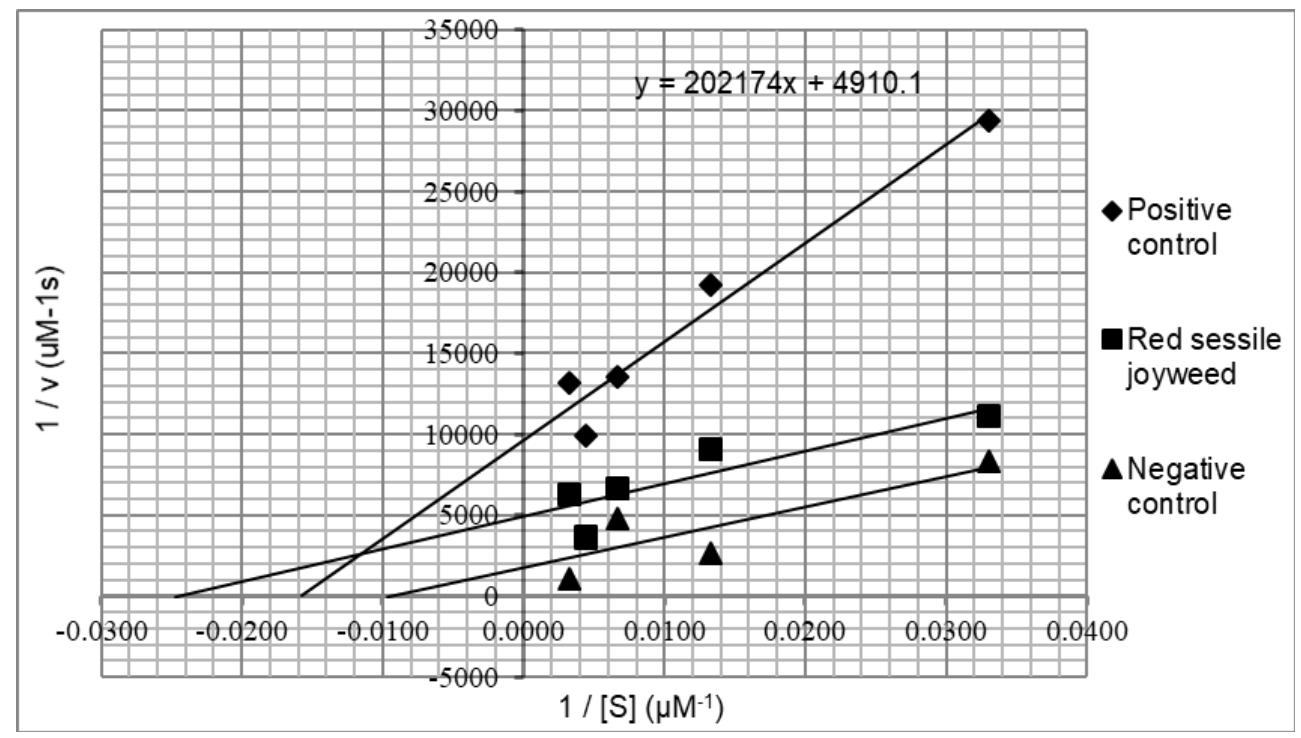

FIGURE 2. Inhibition kinetics for red sessile joyweed (ASR): $\boldsymbol{\nabla}$ in the presence of inhibitor and $\boldsymbol{\Delta}$ in the absence of inhibitor, $\bullet$ the positive control allopurinol

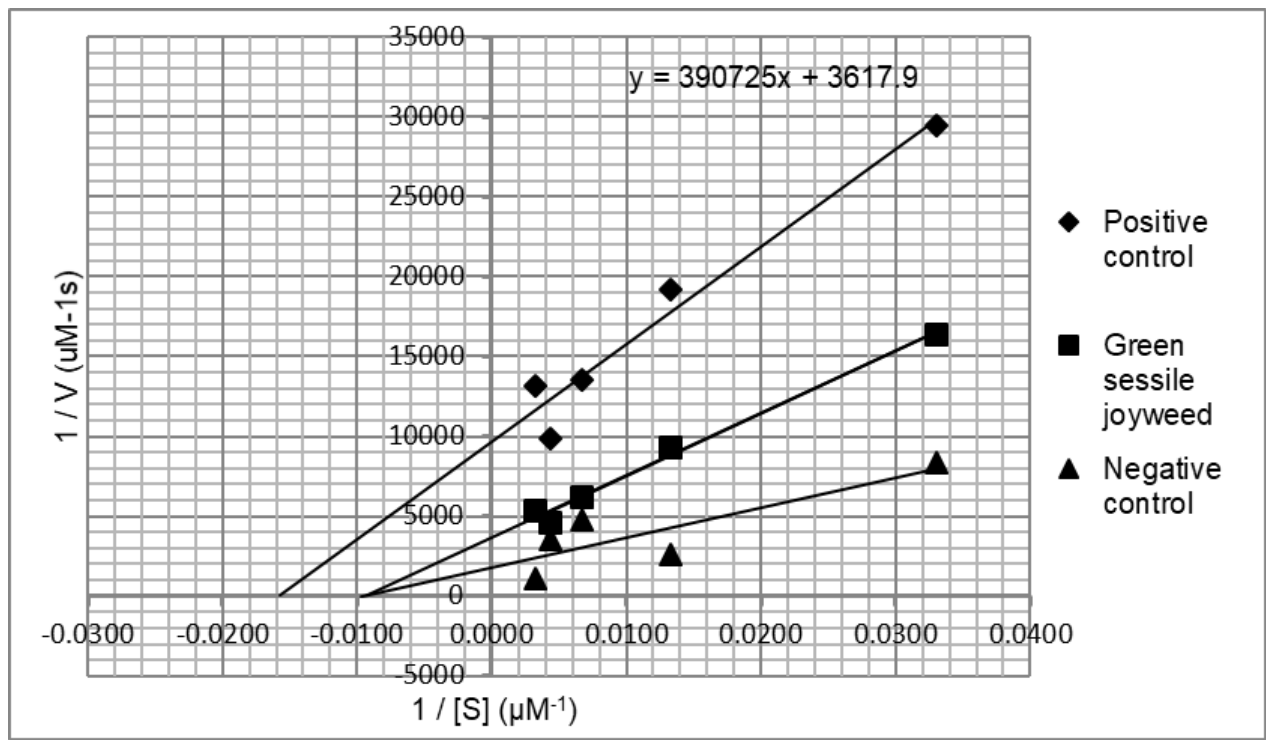

FIGURE 3. Inhibition kinetics for green sessile joyweed (ASG): $\boldsymbol{\boldsymbol { a }}$ in the presence of inhibitor and $\boldsymbol{\Delta}$ in the absence of inhibitor, is the positive control allopurinol 
apigenin have also been identified from $A$. sessilis (Hazli et al. 2018) and have been shown to possess XO inhibitory activity in other studies (Gawlik-Dziki et al. 2017; Qu et al. 2017). However, the mechanism of its inhibitory activity is not well studied yet. Therefore, phytochemical profiling of this plant is recommended in order to give a better insight on its XO inhibitory mechanism. To the best of our knowledge, the present study is the first report on the mode of inhibition of $A$. sessilis on XO enzyme. The findings showed the potential anti-inflammatory potential of $A$. sessilis as a natural source of XO inhibitors for the treatment of gout and hyperuricemia.

\section{CONCLUSION}

Hydromethanolic extract of ASG demonstrated higher XO inhibition than ASR and the $\mathrm{IC}_{50}$ was $557.77 \pm 56.47 \mu \mathrm{g} /$ $\mathrm{mL}$. The results also suggested that the mode of inhibition for ASR and ASG was uncompetitive and non-competitive, respectively. Therefore, ASG can be a potential natural resource of XO inhibitor in the treatment of not only gout, but also diseases associated with hyperuricemia. Further purification of the hydromethanolic extract and in-silico molecular docking study to understand the phytochemistry and mechanism of inhibition of the ASG is strongly recommended.

\section{ACKNOWLEDGEMENTS}

The authors wish to thank the Ministry of Higher Education (MOHE), Malaysia for financial support through FRGS, project number FRGS/2/2014/SG05/TARUC/02/2.

\section{REFERENCES}

Berg, J.M., Tymoczko, J.L. \& Stryer, L. 2007. Biochemistry. 6th ed. New York: W.H. Freeman and Company. pp. 225236.

Borah, A., Yadav, R.N.S. \& Unni, B.G. 2011. In vitro antioxidant and free radical scavenging activity of Alternanthera sessilis. International Journal of Pharmaceutical Sciences and Research 2(6): 1502-1506.

Chaudhary, K., Malhotra, K., Sowers, J. \& Aroor, A. 2013. Uric acid-Key ingredient in the recipe for cardiorenal metabolic syndrome. CardioRenal Medicine 3(3): 208-220.

Chen, L., Yin, H., Lan, Z., Ma, S., Zhang, C., Yang, Z.L.P. \& Lin, B. 2011. Anti-hyperuricemic and nephroprotective effects of Smilax china L. Journal of Ethnopharmacology 135: 399-405.

Corp, N. \& Pendry, B. 2013. The role of western herbal medicine in the treatment of gout. Journal of Herbal Medicine 3(4): 157-170.

Gawlik-Dziki, U., Dziki, D., Świeca, M. \& Nowak, R. 2017. Mechanism of action and interactions between xanthine oxidase inhibitors derived from natural sources of chlorogenic and ferulic acids. Food Chemistry 225: 138145.

Hazli, U.H.A.M., Abdul-Aziz, A., Mat-Junit, S., Chee, C.F. \& Kong, K.W. 2018. Solid-liquid extraction of bioactive compounds with antioxidant potential from Alternanthera sesillis (red) and identification of the polyphenols using UHPLC-QqQ-MS/MS. Food Research International 115: 241-250.

Hossain, A., Faisal, M., Rahman, S., Jahan, R. \& Rahmatullah, M. 2014. A preliminary evaluation of antihyperglycemic and analgesic activity of Alternanthera sessilis aerial parts. BMC Complementary and Alternative Medicine 14: 169 .

Kanagarasu, R., Bhavan, P.S., Rajkumar, G., Nathiya, V., Satgurunathan, T. \& Manjula, T. 2017. Phytochemical characterization of Alternanthera sessilis and assessment of its growth promoting potential on the freshwater prawn Macrobrachium rosenbergii. International Journal of Research Studies in Zoology 3(4): 25-38.

Khuan, C.S., Shahid, M.S.M., Sim, Y.S., Hussein, H., Gaik, O.S., Rosman, A., Liew, C.G., Goh, E. \& Chyn, G.S. 2008. San Francisco: CPG Management of Gout. Health 13: 2128.

Kota, S., Govada, V.R., Anantha, R.K. \& Verma, M.K. 2017. An investigation into phytochemical constituents, antioxidant, antibacterial and anti-cataract activity of Alternanthera sessilis, a predominant wild leafy vegetable of South India. Biocatalysis and Agricultural Biotechnology 10: 197-203.

Lin, S., Zhang, G., Pan, J. \& Gong, D. 2015. Deciphering the inhibitory mechanism of genistein on xanthine oxidase. Journal of Photochemistry and Photobiology B: Biology 153: 463-472.

Othman, A., Ismail, A., Hassan, F.A., Yusof, B.N.M. \& Khatib, A. 2016. Comparative evaluation of nutritional compositions, antioxidant capacities, and phenolic compounds of red and green sessile joyweed. Journal of Functional Foods 21: 263-271.

Qu, L., Ruan, J.Y., Jin, L.J., Shi, W.Z., Li, X.X., Han, L.F., Zhang, Y. \& Wang, T. 2017. Xanthine oxidase inhibitory effects of the constituents of Chrysanthemum morifolium stems. Phytochemistry Letters 19: 39-45.

Rashidinejad, A., Birch, E.J. \& Everett, D.W. 2016. Green tea catechins suppress xanthine oxidase activity in dairy products: An improved HPLC analysis. Journal of Food Composition and Analysis 48: 120-127.

Sahithi, B., Rajani, G.P., Sowjanya, K. \& Gupta, D. 2011. Antiinflammatory activity of ethanolic and aqueous extracts of Alternanthera sessilis Lin. Pharmacologyonline 1: 10391043.

Sweeney, A.P., Wyllie, S.G., Shalliker, R.A. \& Markham, J.L. 2001. Xanthine oxidase inhibitory activity of selected Australian native plants. Journal of Ethnopharmacology 75: 273-277.

Umamaheswari, M. \& Chatterjee, T.K. 2008. Hypouricemic and xanthine oxidase inhibitory activities of the fractions of Coccinia grandis L. Voigt. Oriental Pharmacy and Experimental Medicine 7(5): 477-484.

Vani, M., Rahaman, S.A. \& Rani, A.P. 2018. Detection and quantification of major phytochemical markers for standardization of Talinum portulacifolium, Gomphrena serrata, Alternanthera sessilis and Euphorbia heterophylla by HPLC. Pharmacognosy Journal 10(3): 439-446.

Zhang, C., Wang, R., Zhang, G. \& Gong, D. 2018. Mechanistic insights into the inhibition of quercetin on xanthine oxidase. International Journal of Biological Macromolecules 112: 405-412. 
Department of Bioscience

Faculty of Applied Sciences

Tunku Abdul Rahman University College

Jalan Genting Kelang

53300 Setapak, Kuala Lumpur, Federal Territory

Malaysia
*Corresponding author; email: lohke@tarc.edu.my

Received: 25 September 2019

Accepted: 5 November 2019 